\title{
Rancang Bangun Mesin Pembuat Minuman Kopi Otomatis Berbasis Arduino UNO dengan Kontrol Android
}

\author{
Nini Firmawati ${ }^{1}$,Gentha Farokhi ${ }^{1}$, Wildian Wildian ${ }^{1}$ \\ ${ }^{1}$ Laboratorium Fisika Elektronika dan Instrumentasi, Jurusan Fisika FMIPA Universitas Andalas ,Kampus Unand Limau \\ Manis, Padang, 25163, Indonesia
}

\section{ARTICLE INFORMATION}

Received: February 14, 2019

Revised: March 12, 2019

Available online: March 29, 2019

\section{KEYWORDS}

Arduino uno, android smartphone, bluetooth HC-06, sensor photo diode, selenoid doorlock, selenoid velve, ultrasonic sensors

\section{CORRESPONDENCE}

Phone:+6285293880552

E-mail: firmawatinini@gmail.com

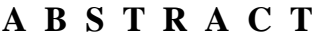

Design of automatic coffee drink maker machine based on arduino uno has been successfully done. Coffee drink maker machine system consists of four parts, namely the selection of the menu of coffee drinks, detection of coffee cups, pouring coffee, sugar and cream and pouring water. The selection of coffee drinks menu is done through applications on android smartphone which is connected to the engine via a bluetooth module HC-06. Detection of cup using the censor of photodiodes. Coffee, sugar, and cream is poured and measured using solenoid doorlock. For pouring water using velve selenoid. There are three menu choices on a machine that are bitter coffee, sweet coffee, and cream coffee. For the production of bitter coffee drinks solenoid doorlock pouring coffee an average 5.03 grams in 3 seconds. For the production of sweet coffee drinks solonoid doorlock coffee pouring an average 5.33 grams sugar and pouring an average 17.50 grams within 8 seconds. For the production of coffee cream solenoid doorlock pouring coffee an average 5.27 grams, pouring sugar an average 17.46 grams and pouring cream an average 5.42 grams within 11 seconds. For pouring water using velve solonoid and stops automatically when the distance between the sensor and the surface of the ultrasonic water reaches $5 \mathrm{~cm}$ by the time pouring over the last 13 seconds.

\section{Pendahuluan}

Perkembangan teknologi menuntut kecanggihan dalam segala hal, tanpa terkecuali dalam penyajian makanan dan minuman cepat saji. Salah satu minuman yang banyak disukai penduduk Indonesia adalah kopi. Kopi dikemas dengan rasa dan aroma yang khas sehingga penikmatnya selalu ingin kembali mencicipinya, apalagi menikmati secangkir kopi sudah melekat dengan gaya hidup masyarakat Indonesia dalam berbagai aktivitas. Indikator ini yang menyebabkan konsumsi kopi di Indonesia meningkat sebesar 6-8 persen per tahunnya.

Proses pembuatan minuman kopi oleh masyarakat Indonesia dilakukan secara manual yaitu dengan membubuhkan kopi dicampur gula dan krim, kemudian diseduh dengan air panas dengan suhu $80^{\circ} \mathrm{C}$ sampai $90^{\circ} \mathrm{C}$ yang proses penakarannya menggunakan konsep perkiraan [1]. Akan tetapi, proses pembuatan minuman kopi secara manual masih membutuhkan waktu yang lama, sedangkan tingkat kesibukan dan berbagai aktifitas yang lebih penting telah menunggu untuk dikerjakan.

Berdasarkan pola aktifitas tersebut, maka sebaiknya diperlukan alternatif untuk mengganti aktifitas tersebut, misalnya dengan menyediakan mesin otomatis. Mesin otomatis merupakan salah satu teknologi yang sengaja diciptakan untuk mengubah suatu kegiatan yang bersifat manual menjadi otomatis dengan tujuan mempercepat proses kegiatan tersebut. Salah satu mesin otomatis yang mulai berkembang pada saat ini adalah mesin pembuat minuman kopi otomatis [2]. 
Beberapa peneliti telah merancang alat pembuat minuman kopi otomatis yaitu berbasis mikrokontroler MSC51. Mesin ini menggunakan sensor cahaya LDR untuk mendeteksi gelas dibawah mesin, menggunakan motor steper dan kran elektrik untuk mendukung alat ini. Pengontrolan mesin mengunakan personal computer dan proses pemesanan minuman harus langsung ketempat mesin itu berada. Keluaran minuman yang dihasilkan yaitu minuman kopi panas dengan rasa yang selalu sama atau tidak bervariasi [3]. Kemudian, peneliti lain juga telah merancang mesin pembuat kopi otomatis berbasis mikrokontroler dengan menggunakan tombol pada mesin, sehingga pengguna harus langsung ke tempat mesin berada untuk memesan minuman. Penakaran bahan menggunakan motor $d c$ dan screw conveyor sesuai dengan pilihan rasa yang terdapat pada tombol. Minuman kopi yang dihasilkan sesuai dengan tombol yang ditekan, seperti pilihan rasa kopi manis, kopi pahit dan kopi krim [4]. Telah dilakukan juga pembuatan kopi pada mesin dimulai dengan pembacaan suhu air oleh sensor LM-35 dilanjutkan dengan pengisian gula, kopi dan krim menggunakan doorlock yang sudah dimodifikasi. Pengontrolan mesin ini mengunakan tombol push button. Keluaran minuman yang dihasilkan berupa minuman kopi pahit, kopi manis dan kopi tanpa gula sesuai pilihan konsumen [1].

Berdasarkan latar belakang yang telah diuraikan, maka perlu ditingkatkan sistem mesin pembuat minuman kopi otomatis agar lebih lengkap dan mudah digunakan. Dalam penelitian ini dirancang mesin pembuat minuman kopi otomatis menggunakan modul Arduino Uno. Untuk pengontrolannya menggunakan Smartphone berbasis android dengan teknologi wireless bluetooth. Pengontrolan tersebut dilakukan melalui aplikasi yang dibuat dan direalisasikan dalam sebuah mesin pembuat minuman kopi otomatis. Proses penuangan gula, kopi dan krim menggunakan doorlock yang telah dimodifikasi. Doorlock berfungsi sebagai sebuah sub sistem yang akan melakukan pengisian takaran kopi, gula dan krim ke dalam wadah penampung sementara. Mesin juga akan dilengkapi dengan sensor fotodioda sebagai pendeteksi ada atau tidaknya cangkir di bawah mesin dan sensor ultrasonik sebagai penakaran proses penuangan air panas yang akan digunakan. Perancangan software pada penelitian ini menggunakan bahasa $\mathrm{C}$ yang akan ditanamkan pada mikrokontroler Atmega328.

\section{Metode}

\subsection{Diagram Alir Penelitian dan Bentuk Fisik Alat}

Prinsip kerja perangkat keras ini akan beroperasi ketika mendapatkan perintah dari aplikasi pada smartphone android. Terdapat beberapa pilihan menuuntuk minuman kopi yang akan dibuat. Setelah memilih pilihan yang ada pada aplikasi, mesin akan bekerja diawali dengan pendeteksian cangkir dengan sensor fotodioda. Keluaran dari modul sensor ini berupa data digital berupa tegangan keluaran yang selajutnya dimasukkan kedalam input mikrokontrloer arduino uno berupa data. Data yang masuk akan diolah arduino uno untuk mengaktifkan doorlock dan keran elektrik. Relay akan menjembatani pengaktifan doorlock yang memiliki fungsi untuk melakukan aktifitas pengisian kopi, gula, sesuai dengan pilihan rasa yang dipilih pada aplikasi. Keran elektrik berfungsi untuk proses penuangan air. Keran akan berhenti menuangkan air berdasarkan jarak permukaan air dengan sensor Ultrasonic PING. Diagram alir cara kerja alat ditunjukkan pada gambar 1

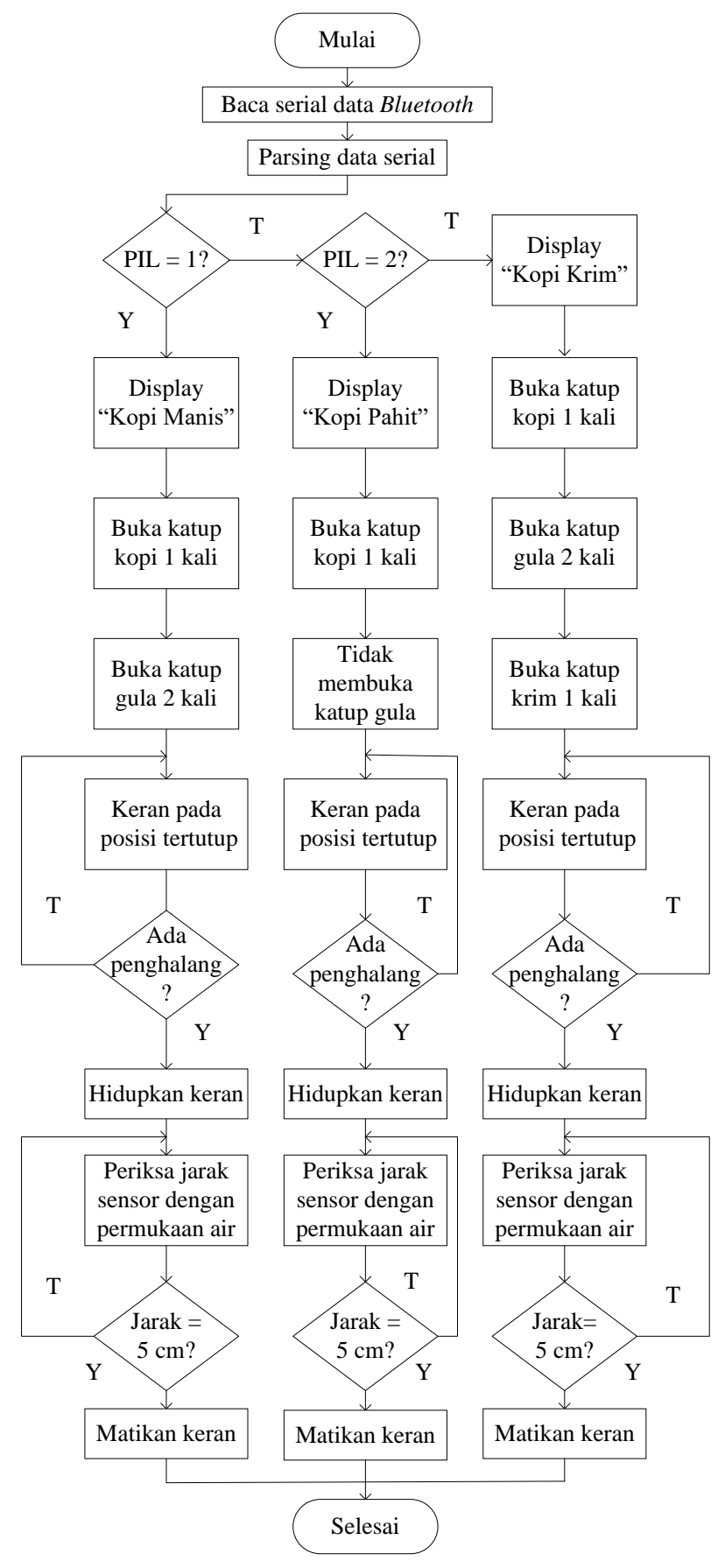

Gambar 1. Digram alir cara kerja mesin pembuat minuman kopi otomatis

Alat yang dirancang terdiri dari 2 box, satu box untuk tempat air panas (dispenser) dan box kedua tempat mesin pembuat minuman kopi otomatis. Bentuk fisik alatnya dapat dilihat pada gambar 2. 


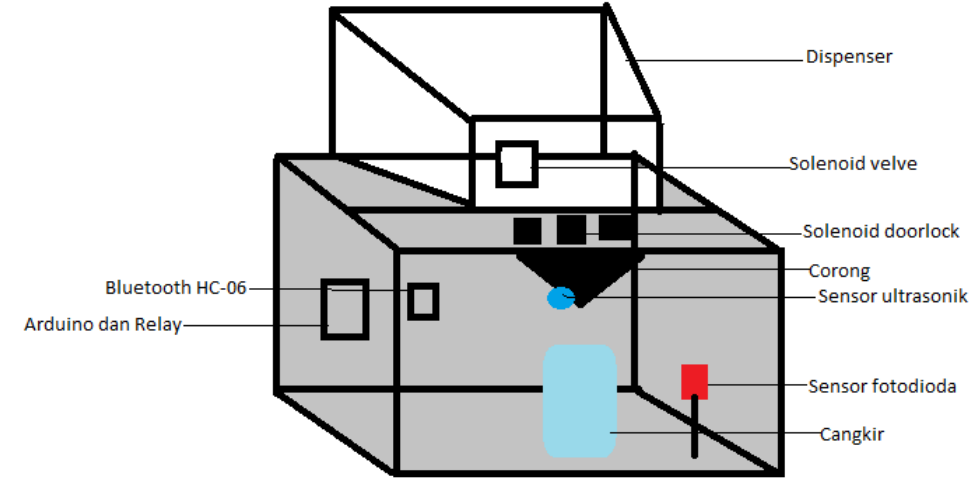

Gambar 2. Bentuk fisik alat pembuat minuman kopi otomatis

\subsection{Perancangan Alat}

Rancang bangun mesin pembuat minuman kopi otomatis pada penelitian ini terdiri dari 3 bagian utama yaitu perancangan perangkat keras (hardware), perangkat lunak (software) dan perancangan aplikasi android. Perangkaian perangkat keras tediri dari catudaya $+12 \mathrm{~V}$, rangkaian sensor fotodioda, rangkaian sensor ultrasonik, rangkaian relay, perancangan sistem solenoid, dan perancangan aplikasi android. Perangkat (program) ditulis dalam bahasa $\mathrm{C}$, disimpan dalam file dan ditanamkan ke arduino melalui Arduino IDE dalam komputer. Perancangan aplikasi android ini dirancang dengan menggunakan program MITApp Inventor.

\section{Hasil dan Diskusi}

\subsection{Perancangan catu daya}

Nilai tegangan catu daya yang diperlukan pada rancangan mesin ini adalah sebesar $+12 \mathrm{~V}$ dc. Untuk itu digunakakan rangkaian catu daya power supply switching yang menghasilkan tegangan $12 \mathrm{~V}$. Setelah catu daya selesai dirangkai kemudian diuji besar tegangan keluaran catu daya tersebut. Dari hasil pengukuran didapat tegangan keluaran catu daya sebesar 12,2 V. Besar tegangan ini sudah bisa digunakan karena mendekati $+12 \mathrm{~V}$.

\subsection{Hasil karakterisasi sensor fotodioda}

Pada tahap karakterisasi sensor fotodioda yang akan dihitung adalah tegangan keluaran sensor berdasarkan variasi jarak antara LED dengan fotodioda dan pengujian objek penghalang sinar LED. Tegangan keluaran yang dihitung dimulai dari jarak $1 \mathrm{~cm}-$ $10 \mathrm{~cm}$, dan divariasikan setiap $1 \mathrm{~cm}$. Grafik hasil dari pengukuran dapat dilihat pada Gambar 3.

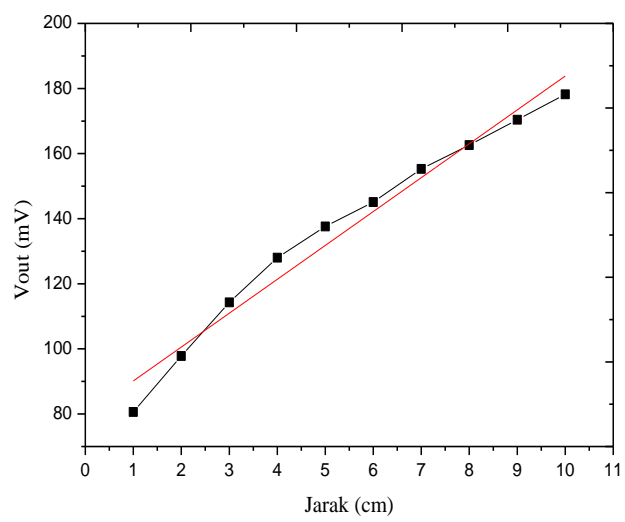

Gambar 3. Grafik tegangan keluaran sensor fotodioda terhadap jarak LED
Berdasarkan gambar 3 terlihat bahwa tegangan keluaran semakin besar apabila jarak cangkir yang diletakkan diantara LED dan fotodioda semakin jauh. Ketika jaraknya semakin jauh maka intensitas cahaya LED yang sampai ke fotodioda akan semakin berkurang sehingga arus yang melalui fotodioda akan semakin sedikit. Hal ini menyebabkan hambatan pada fotodioda akan semakin besar sehingga tegangan keluaran semakin besar pula.

Pada tahap pengujian objek penghalang sinar LED, objek yang digunakan adalah cangkir. Pengujian ini dilakukan untuk mengetahui apakah cangkir dapat meghalangi sinar dari LED ke fotodioda. Hasil uji dari daya halang sinar LED terhadap beberapa jenis cangkir diperlihatkan pada tabel 1 .

Pada tabel 1 dapat dilihat daya tembus sinar LED tehadap masing-masing bahan pembuat cangkir berbeda-beda. Cangkir dari bahan keramik memiliki permukaan yang mengkilap dan tidak tembus pandang, sehingga sinar yang datang akan terhalang. Untuk cangkir yang terbuat dari bahan kaca dan plastik bening, sinar LED dapat menembus bahan tersebut, sedangkan untuk cangkir plastik yang berwarna maka sinar LED tidak dapat menembusnya.

Tabel 1. Hasil pengujian ojek penghalang fotodioda

\begin{tabular}{cccc}
\hline \multirow{2}{*}{ No } & \multicolumn{2}{c}{ Jenis Cangkir } & Sinar LED \\
\cline { 2 - 3 } & Bahan & Warna & \\
\hline 1 & Keramik & Semua Warna & Terhalang \\
\hline 2 & Kaca & Bening & Tidak Terhalang \\
\hline 3 & Plastik & Bening & Tidak Terhalang \\
\hline 4 & Plastik & Bewarna & Terhalang \\
\hline
\end{tabular}

\subsection{Pengujian rangkaian sensor ultrasonik}

Pengujian ini bertujuan untuk penakaran proses penuangan air kedalam cangkir. Pada pengujian ini sensor ultrasonik akan mendeteksi jarak permukaan air dalam cangkir dengan sensor. Jarak maksimal permukaan air dengan sensor yaitu $5 \mathrm{~cm}$ yang menandakan air dalam cangkir sudah penuh terisi (jarak permukaan air dengan bibir cangkir $2 \mathrm{~cm}$ ) dan menghentikan proses penuangan air. Untuk mengaktifkan sensor ultrasonik, Pin Vss dihubungkan ke ground, dan pin Vdd dihubungkan ke catu daya dengan tegangan $5 \mathrm{~V}$, kemudian pin SIG dihubungkan ke pin mirokontroler P3_6, sedangkan untuk keluaran program diatur pada P2_3.

\subsection{Pengujian rangkaian solenoid}

Terdapat 2 tahap pengujian rangkaian solenoid yaitu pengujian solenoid velve dan pengujian solenoid doorlock. Pengujian solenoid velve didapat bahwa untuk bekerja dengan baik, solenoid velve memerlukan tekanan air yang besar sehingga air dapat mengalir maksimal. Pada penelitian ini tekanan air yang terdapat pada pemanas / dispenser tidak besar sehingga air tidak dapat mengalir maksimal. Untuk mencapai kecukupan air untuk mengisi segelas kopi, waktu rata-rata solenoid velve dalam kondisi on adalah selama 13 detik.

Pengujian solenoid doorlock bertujuan untuk menghasilkan takaran kopi sesuai dengan menu yang disediakan pada mesin. Pengujian ini menggunakan 3 buah solenoid doorlock yang masing-masing digunakan untuk menuangkan kopi, gula dan krim. Rata-rata hasil pengujian solenoid doorlock dapat dilihat pada tabel 2 dan tabel 3. 
Tabel 2 Komposisi bahan

\begin{tabular}{|c|c|c|c|}
\hline Keterangan & $\begin{array}{c}\text { Komposisi } \\
\text { kopi } \\
\text { (gram) }\end{array}$ & $\begin{array}{l}\text { Komposisi } \\
\text { gula (gram) }\end{array}$ & $\begin{array}{l}\text { Komposisi } \\
\text { krim } \\
\text { (gram) }\end{array}$ \\
\hline Minuman kopi pahit & 5,08 & - & - \\
\hline Minuman kopi manis & 5,33 & 17,50 & - \\
\hline Minuman kopi krim & 5,27 & 17,46 & 5,42 \\
\hline \multicolumn{4}{|c|}{ Tabel 3 Waktu pembuatan } \\
\hline Keterangan & $\begin{array}{c}\text { Waktu } \\
\text { penuangan } \\
\text { kopi (detik) }\end{array}$ & $\begin{array}{c}\text { Waktu } \\
\text { penuangan } \\
\text { gula (detik) }\end{array}$ & $\begin{array}{c}\text { Waktu } \\
\text { penuangan } \\
\text { krim (detik) }\end{array}$ \\
\hline Minuman kopi pahit & 3 & - & - \\
\hline Minuman kopi manis & 3 & 5 & - \\
\hline Minuman kopi krim & 3 & 5 & 3 \\
\hline
\end{tabular}

Berdasarkan tabel 2 dan tabel 3 dapat dilihat proses penuangan kopi gula dan krim. Untuk pembuatan kopi pahit solenoid doorlock hanya menuangkan kopi dengan komposisi rata-rata 5,08 gram dalam waktu 3 detik. Untuk pembuatan kopi manis solenoid doorlock akan menuangkan kopi dengan rata-rata komposisi 5,33 gram dalam waktu 3 detik dan menuangkan gula dengan komposisi rata-rata 17,50 gram dalam waktu 5 detik. Untuk pembuatan kopi krim solenoid doorlock akan menuangkan kopi dengan rata-rata komposisi 5,27 gram dalam waktu 3 detik, menuangkan gula dengan komposisi rata-rata 17,46 gram dalam waktu 5 detik dan menuangkan krim dengan komposisi rata-rata 5,42 gram dengan waktu 3 detik.

\subsection{Perancangan aplikasi android}

Perancangan tampilan android dirancang dengan menggunakan program MITApp Inventor. Bentuk tampilan aplikasi android tersebut dapat dilihat pada gambar 4.

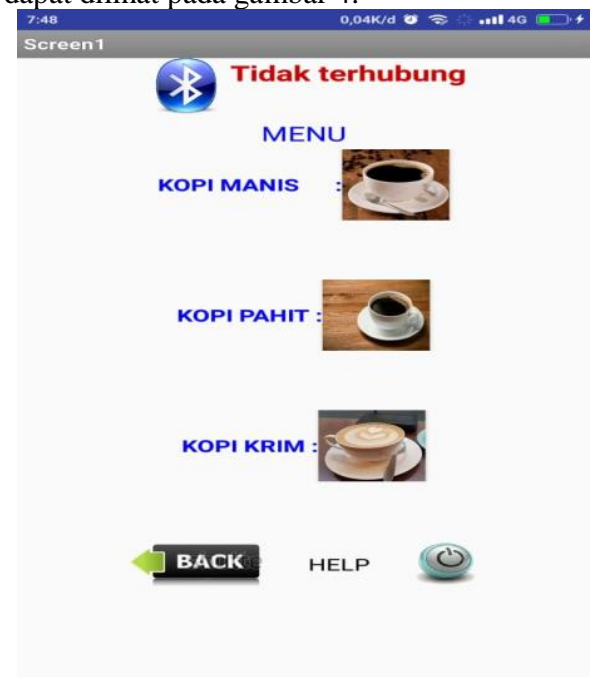

Gambar 4. Tampilan aplikasi android.

Berdasarkan gambar 4 dapat dilihat terdapat 3 pilihan menu pada aplikasi yaitu menu untuk pembuatan minuman kopi manis, kopi pahit dan kopi krim. Prosedur untuk menjalankan aplikasi ini dapat dilihat pada diagram alir yang ditunjukkan pada Gambar 5. Pertama pengguna akan diminta mengaktifkan koneksi bluetooth dan melakukan pairing dengan modul bluetooth HC. Setelah terkoneksi, smartphone android sudah dapat digunakan untuk memilih pilihan kopi yang tersedia. Data dari pilihan kopi yang dipilih tersebut akan dikirim ke mikrokontroler Arduino.

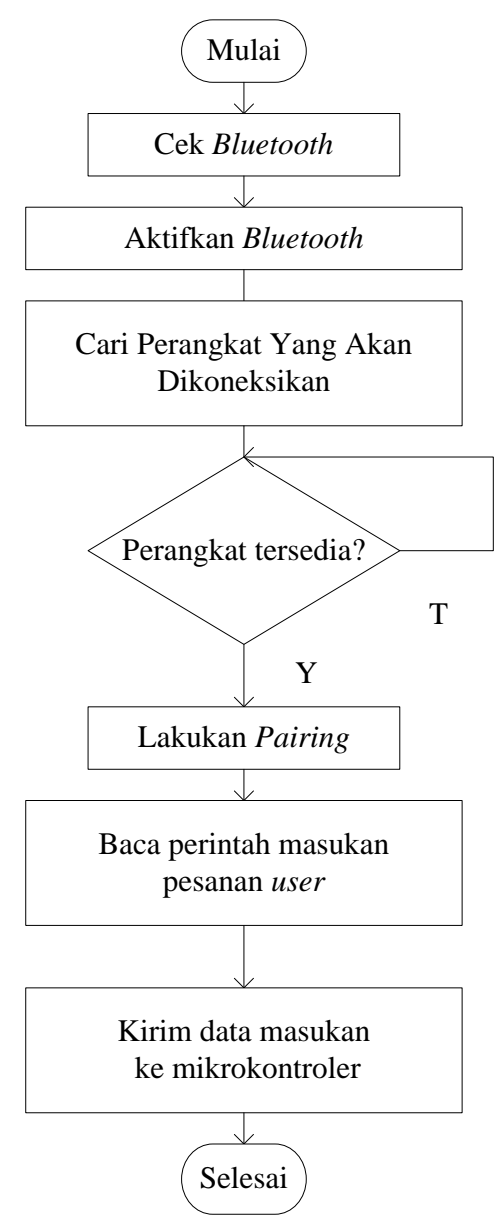

Gambar 5. Diagram Alir aplikasi android.

3.6. Pengujian program

Pengujian program bertujuan untuk melihat apakah program berjalan sesuai dengan yang diharapkan. Program ditulis dalam bahasa pemograman arduino dan di-compile ke program arduino. Pada penelitian ini terdapat 2 tahapan pengujian program yaitu pengujian program ketinggian permukaan air dan pengujian program aplikasi android.

Pengujian tahap pertama dilakukan menguji program ketinggian permukaan air dengan menggunakan LED. Tujuannya adalah untuk mengetahui apakah port pada mikrokontroler yang telah diatur pada program mengeluarkan keluaran (logika high atau low) ketika mendeteksi ketinggian air. Setelah dilakukan pengujian didapatkan hasil bahwa ketika jarak sensor ke permukaan air belum mencapai $5 \mathrm{~cm}$ LED belum menyala yang menandakan port 2_3 masih low, sedangkan ketika jaraknya sudah mencapai $5 \mathrm{~cm}$, maka LED akan menyala dan menandakan port 2_3 mengeluarkan logika high.

Pengujian tahap kedua dilakukan menguji jarak jangkauan bluetooth HC-06. Terdapat 2 parameter pada pengujian jangkauan bluetooth yaitu pengujian ruangan tanpa penghalang dan ruangan dengan penghalang. Pengujian ruangan tanpa penghalang dilakukan pada ruang terbuka tanpa ada penghalang material dan jaringan lain. Pengujian ruangan dengan penghalang dilakukan dengan memberi penghalang antara modul bluetooth HC-06 dengan perangkat bluetooth pada android berupa dinding pembatas atau material lainnya. Hasil pengujian jangkauan bluetooth dapat dilihat pada tabel 4 dan tabel 5 . 
Tabel 4 Hasil pengujian ruangan tanpa penghalang

\begin{tabular}{lcc}
\hline Jarak & Keterangan & $\begin{array}{c}\text { Koneksi ke } \\
\text { mesin }\end{array}$ \\
\hline $5 \mathrm{~m}$ & Terdeteksi & Sukses \\
$10 \mathrm{~m}$ & Terdeteksi & Sukses \\
$15 \mathrm{~m}$ & Terdeteksi & Sukses \\
$20 \mathrm{~m}$ & Sinyal lemah & Sukses \\
$25 \mathrm{~m}$ & Sinyal lemah & Sukses \\
$30 \mathrm{~m}$ & Tidak terdeteksi & Gagal \\
$35 \mathrm{~m}$ & Tidak terdeteksi & Gagal \\
\hline
\end{tabular}

Pada tabel 4 dapat dilihat jarak maksimal dari suatu modul bluetooth yaitu 25 meter. Pengujian pada ruangan terbuka dilakukan dalam kondisi cuaca yang bagus, tidak ada angin kencang dan petir sehingga sinyal yang dihasilkan merupakan sinyal terbaik. Adapun jarak idealnya yaitu meter 5 meter -25 meter.

Tabel 5 Hasil pengujian ruangan dengan penghalang

\begin{tabular}{lcc}
\hline Jarak & Keterangan & Koneksi ke mesin \\
\hline $5 \mathrm{~m}$ & Terdeteksi & Sukses \\
$10 \mathrm{~m}$ & Terdeteksi & Sukses \\
$15 \mathrm{~m}$ & Sinyal lemah & Sukses \\
$20 \mathrm{~m}$ & Tidak terdeteksi & Gagal \\
$25 \mathrm{~m}$ & Tidak terdeteksi & Gagal \\
\hline
\end{tabular}

Pada table 5 dapat disimpulkan bahwa jaringan yang dapat dijangkau terhadap access point perangkat bloetooth $\mathrm{HC}-06$ maksimal 15 meter. Jarak tersebut mengalami pengiriman data yang lambat dikarenakan sinyal yang lemah. Adapun jarak idelanya adalah 5 meter hingga 15 meter. Berdasarkan hasil kedua pengujian tersebut jangkauan access point perangkat bluetooth android dan bloetooth HC-06 serta transmisi data lebih baik dilakukan pada ruangan tanpa penghalang.

\section{Kesimpulan}

Sistem mesin pembuat minuman kopi otomatis berbasis Arduino UNO dengan kontrol android telah berhasil dilakukan. Pada sistem otomatisasi, fotodioda mendeteksi cahaya dari LED dengan jarak penghalang $5 \mathrm{~cm}$ dengan tegangan keluaran $4,4 \mathrm{~V}$. Untuk pembuatan kopi pahit solenoid doorlock menuangkan kopi dengan komposisi rata-rata 5,08 gram dalam waktu 3 detik. Untuk pembuatan kopi manis solenoid doorlock menuangkan kopi dengan rata-rata komposisi 5,33 gram dalam waktu 3 detik dan menuangkan gula dengan komposisi rata-rata 17,50 gram dalam waktu 5 detik. Untuk pembuatan kopi krim solenoid doorlock akan menuangkan kopi dengan rata-rata komposisi 5,27 gram dalam waktu 3 detik, menuangkan gula dengan komposisi rata-rata 17,46 gram dalam waktu 5 detik dan menuangkan krim dengan komposisi rata-rata 5,42 gram dalam waktu 3 detik. Jarak maksimum yang dapat dijangkau oleh Modul bluetooth HC-06 pada mesin terhadap perangkan bluetooth pada android pada ruang terbuka yaitu 25 meter dan pada ruang tertutup yaitu 15 meter.

\section{Ucapan Terimakasih}

Penulis mengucapkan terimakasih pada pihak Laboratorium Elektronika dan Instrumentasi Jurusan Fisika FMIPA Universitas Andalas yang telah memberikan kemudahan akses dan peminjaman alat ukur standar yang berkaitan dengan penelitian ini.

\section{Daftar Pustaka}

[1] H, Yenni dan M., Ridwan, "Implementasi Kendali Mikrokontroler ATMega8535 Pada Alat Pembuat Minuman Kopi Otomatis", Jurnal Edukasi dan Penelitian Informatika, Vol.1, No.2, 2015

[2] Wamiliana dan D, Kurniawan, "Penerapan Konsep Finite State Automata Pada Mesin Pembuat Minuman Kopi Otomatis”, Jurnal Komputasi, Vol.1, No.1,2013,

[3] T.U. Kalsum, dan P.W., Ginta, "Rancangan Alat Pembuat Minuman Kopi Otomatis Menggunaka Mikrokontroler MCS51", Jurnal Media Infotama, Vol.8, No.2, 2012,

[4] B,A., MarellaHarianto dan Wibowo, M.C., "Rancang Bangun Mesin Pembuat Minuman Kopi Otomatis Berbasis Mikrokontroler Dengan Metode Fuzzy", Jurnal of Control and Network System, Vol.4, No.2, 2012 , 